Розглядаеться питання забезпечення теплового режиму анодного блоку магнетрона иляхом заміни системи повітряного охолодження на системурідинного охолодження. Стверджуеться, що система рідинного охолодження найбільш підходяща для магнетронів, які в даний час передбачають систему повітряного охолодження, однак не розраховані на тривалу роботу в складі промислових мікрохвильових установок. Організація системи рідинного охолодження дозволить магнетрон працюовати тривалий час без перегріву $і$ в сприятливих умовах, при яких виключено забивання частинками $i$ пилом поверхні теплообміну $і$ виникнення перегріву поверхні анодного блоку. Основним елементом розроблюваної системи рідинного охолодження є сорочка охолодження, що представляє собою кільщевий канал з теплопровідного матеріалу. Сорочка охолодження кріпиться безпосереднъо на анодний блок, при цьому ступінь стиснення поверхонь $і$ товщина повітряного зазору повинні забезпечити мінімальне сумарне термічний опір. Для визначення коефічієнтів тепловіддачі отримана емпірична залежність, яка відображає той факт, що при охолодженні анодного блоку ращіональними є в'язкі $i$ перехідні режими руху. Визначено основні теплові характеристики процесу охолодження, що включають коефічієнт теплопередачі, зміну температури теплоносія, максимально допустиму температуру на вході. Розрахунки проведені для двох видів теплоносї̈в: вода $і 54$ \% водний розиин етиленгліколю. Запропоновано схему системи рідинного охолодження, яка передбачає охолодження від 1 до 6 магнетронів. Застосування даного схемного рішення $і$ вибір рачіональних розрахункових режимних дозволяє вирішити проблему підвищення ефективності виробництва $i$ надійності роботи мікрохвильової техніки

Ключові слова: система охолодження, анод, магнетрон, термічний опір, теплоносій, теплоносій, коефічієнт тепловіддачі
UDC 62-713.82/621.385

DOI: $10.15587 / 1729-4061.2019 .175470$

\section{DESIGNING A SYSTEM OF LIQUID COOLING FOR INDUSTRIAL MICROWAVE INSTALLATIONS}

I. Boshkova

Doctor of Technical Sciences, Associate Professor*

E-mail: boshkova.irina@gmail.com

A. Titlov

Doctor of Technical Sciences, Professor, Head of Department* E-mail: titlov1959@gmail.com

N. Volgusheva

$\mathrm{PhD}$, Associate Professor*

E-mail: natvolgusheva@gmail.com

N. Ko I e s n y c he n k o $\mathrm{PhD}$, Associate Professor Department of Technical Provision

Odessa Military Academy Fontanska doroha str., 10, Odessa, Ukraine, 65009

E-mail: kolesnychenko.natalia@gmail.com

T. S a g a I a

PhD, Associate Professor*

E-mail: sagala.onaft@gmail.com

*Department of Heat-and-Power Engineering and

Fuel Pipeline Transportation

V. S. Martynovsky Institute of Refrigeration,

Cryotechnologies and Ecoenergetics

Odessa National Academy of Food Technologies Kanatna str., 112, Odessa, Ukraine, 65039

\section{Introduction}

There are patterns in the interaction between a microwave electromagnetic field and polar dielectrics, for example, the volumetric heating of a material and the local heating. As a result, microwave treatment could lead to new effects and the emergence of unique properties of materials [1-3]. Microwave technologies are attractive in that they make it possible to obtain qualitatively new materials, which is impossible to achieve by using other thermal processing methods. In this regard, there is understandable interest in the use of microwave heating, which has been particularly active in recent times. Accordingly, there has been increased interest in the construction of industrial microwave devices, which is associated with a sig- nificant reduction in the cost of components for microwave equipment. Microwave (dielectric) heating that employs energy of an alternating electromagnetic field in the microwave range is promising for use in various industries $[4,5]$. Feasibility of microwave heating is predetermined by a series of indicators, which include [6]:

- a possibility of instantaneous managed heating or local heating;

- reduced space allocated for storage or equipment resulting from a significant decrease in the processing cycle;

- less shrinkage and lower losses during treatment;

- better quality of treated products;

- significant reduction in heat losses into the environment and reducing its pollution;

- high bactericidal effect of microwave energy; 
- inertia-free heating and a possibility to fully automate the process.

However, the introduction of microwave technology is inhibited by some unresolved important technical issues. One of these is the task on ensuring a thermal mode for a microwave energy generator. In this case, the issue on providing a thermal regime for the magnetron should be paid more attention since an increase in the anode unit's surface temperature above permissible leads to a rapid failure in the generator operation. Anode unit is the main part of the magnetron. The anode unit consists of a copper cylinder, with cavities in the center, which are a ring cavity resonator system. The magnetron's electron efficiency, which defines the efficiency of an electron flux energy conversion into the energy of high-frequency fluctuations, is quite high (up to $80 \%$ ), but almost all remaining part is released in the form of heat on the anode unit that causes its heating. To cool it, ribbed radiators are mounted at the surface of low-power magnetrons, which are manufactured for microwave ovens. There is some interest in the use of such magnetrons for industrial installations, which necessitates making their cooling system more reliable. Industrially-produced low-power magnetrons are designed for household microwave ovens. When they are used at industrial installations, such magnetrons often overheat and fail. In this case, the appropriateness of their application relates to that they are quite reliable (subject to maintaining thermal regimes) and are much cheaper than magnetrons at high output power. In addition, a uniform distribution of microwave energy is easier to achieve by applying several low-power magnetrons rather than one of high power. The task on maintaining steady thermal mode for magnetrons with an output power up to $1 \mathrm{~kW}$ at their long-term use at industrial installations could be solved by replacing an air-cooling system (ACS) with the system of liquid cooling (SLC). In this case, it is necessary to substitute the ribs that are installed on the anode unit with a cooling jacket, tightly fitted to the surface of the anode. Transition to SLC must be accompanied by thermal engineering calculations, the result of which would be to define the operating parameters for the system. The relevance of the current work relates to that the system that maintains thermal modes (SMTM) at low-power magnetrons currently produced has not been modernized up to now, because their application was limited to operating conditions for household microwave ovens. A system of air cooling is more suitable for a brief operation under household conditions, but, when used industrially, it does not warrant reliability in maintaining the required temperature regime.

\section{Literature review and problem statement}

Paper [7] proposed a method to modify the cooling system for commercially produced magnetrons used in household and industrial microwave ovens. The modification implies a transition from the air to water cooling system. It was shown that liquid cooling could be arranged by coiling a thin-walled copper tube directly on the device body or by installing a water radiator in the form of a mono unit. However, there are no results from thermal calculations for the systems being developed. The lack of reliable dependences, which make it possible to estimate the mode parameters for SLC operation, could hamper the design. Structural considerations, as well as coupling components at microwave devices, were described in [8]. The data reported allow the authors to establish fundamental concepts for designing microwave devices. However, cooling systems and their modernization have been paid insufficient attention to. Study [9] considers patterns in converting electrical energy into a microwave field energy and reports results from modelling frequency characteristics of magnetrons under continuous mode. The study into frequency characteristics of magnetrons and their analysis reveal that the fluctuation frequency at magnetron generators is linked to the electron-wave interaction mechanism, a device operation mode, conditions and characteristics of its operation, as well as other factors. That emphasizes the importance of designing a reliable system to provide for the thermal mode of the magnetron. A deviation from the requirements to maintain stable temperature of the anode unit shifts the magnetron's working point for output frequency. The working point's shift leads to a deterioration in the effectiveness of magnetron operation as an energy source. In addition, overheating reduces service life of the magnetron.

The importance to develop reliable SMTM was noted in [10]. The paper indicates that the influence of change in temperature on the equipment reliability is manifested, first, by the change (reversible and irreversible) in electrical parameters and characteristics of products, second, by the dependence of products' indicators of reliability on temperature. One of the main stages during design that defines the direction for the entire structure of the system to ensure thermal regimes is the choice of a cooling technique for magnetrons [11]. The paper reports results from experimental research into possible instability of frequency at magnetrons, including results from studying the influence of temperature at anode unit on generation frequency. It was established that increasing the temperature of an anode unit from $20^{\circ} \mathrm{C}$ to $60{ }^{\circ} \mathrm{C}$ leads to a decrease in the generation frequency of magnetron by $0.1 \%$. Stabilization of the anode unit's temperature contributes to the stabilization of frequency. A study into the cooling system of a low-power magnetron using heat exchange with natural convection was described in [12]. The authors revealed the defining effect of temperature on shift in the magnetron power.

Possibilities to improve ACS were considered in [13]. It is shown that decreasing the thickness of a rib from $0.6 \mathrm{~mm}$ to $0.5 \mathrm{~mm}$ leads to weight loss by $16.7 \%$ and to the intensification of heat exchange. However, the data cover the magnetrons that work as part of household microwave ovens. Given the feasibility of transition to SLC when designing industrial plants, there is a need to calculate a heat transfer coefficient from the surface of the anode unit to a heat-carrier. When employing liquid cooling for the anode unit, a heat-carrier circulates along the annular channel. In [14], authors applied an estimation-analytical method to determine efficiency of heat transfer intensification along an annular channel at central heat supply. At the same time, a given work does not consider a swirl of the flow inside the annular channel. In [15], it was experimentally established that using different-shaped intensifiers at a convex heated surface heat led to a significant increase in the efficiency of heat output. The heat transfer coefficient was 1.8 times higher than that for smooth annular channels. That suggests the need for the proper selection of estimation formulae that would reflect actual conditions for the progress of heat exchange processes. It was found in [16] that, although there are different dependences to determine a heat transfer coefficient in annular channels, the scope of their application is not necessarily consistent with the conditions for heat transfer in the magnetrons' cooling jacket. 
Those low-power magnetrons that are industrially produced are designed for household microwave ovens, which are operated over a short time under comfortable conditions. Air cooling system in this case is optimal. At the same time, there are attempts to engage the microwave technologies to thermally treat materials, which, as stated in [4], are becoming increasingly popular in the world. Implementation of microwave technologies requires reliable and efficient equipment. These issues are solved by using dispersed low-power magnetrons, equipped with a cooling system that prevents clogging the heat transfer surface, as well as temperature spikes. All this suggests that it might prove expedient to replace ACS with SLC for industrial microwave installations. Because microwave industrial equipment is under development, no design calculations for SLC has been carried out up to now. The main task related to modernizing a cooling system is to study heat exchange in the annular channel of the anode unit's cooling jacket and to estimate the SLC operability.

\section{The aim and objectives of the study}

The aim of this work is to study analytically the functioning of a system of liquid cooling of the magnetron's anode unit with an output power of $1.0 \mathrm{~kW}$. This would make it possible to modernize the cooling system in order to subsequently use magnetrons for industrial microwave devices.

To accomplish the aim, the following tasks have been set:

- to analyze the effect of thermal resistances in the heat conductivity of contact spots and an air gap, emerging when installing a cooling jacket, on heat transfer from the surface of the anode unit to a heat carrier;

- to establish a dependence for the calculation of a heat transfer coefficient from the surface of the anode unit to a heat carrier that circulates in the cooling jacket and to calculate the cooling mode of the anode unit, to determine the maximal temperatures of heat-carriers in a circulation contour in accordance with the permissible value for the anode unit's surface temperature;

- to compare heat carriers in terms of heat transfer efficiency and to propose a structural solution for the system of liquid cooling for an industrial installation.

\section{Materials and methods to study heat exchange in the anode unit's cooling jacket}

To implement heat removal from the surface using SLC, it is necessary to replace ACS ribs at the surface of the anode unit that are mounted at industrially produced magnetrons of low power with a liquid cooling jacket. To ensure trouble-free operation, SLC should be equipped with sensors for pressure, temperature, and flow rate.

Fig. 1 shows a schematic of the anode unit at a commercially available magnetron in the original form and after replacing ACS with SLC.

Working fluids (heat-carriers) to fill SLC are selected according to the following criteria:

- range of operating temperatures: $-20 \ldots 50{ }^{\circ} \mathrm{C}$;

- a liquid must be non-toxic;

- no chemical reactivity;

- best value;

- availability.
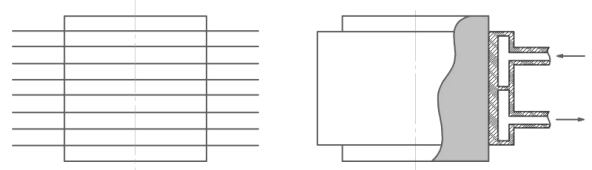

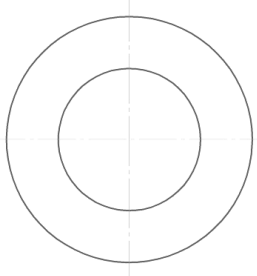

$a$

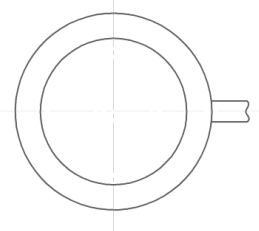

$b$
Fig. 1. Schematic of the magnetron's anode unit with the cooling system elements: $a$ - magnetron with ACS elements; $b$ - modernized magnetron with SLC

In accordance with these criteria, we chose to use water and a $54 \%$ aqueous solution of ethylene glycol. Water is used for operation at an ambient temperature from $2{ }^{\circ} \mathrm{C}$ to $50{ }^{\circ} \mathrm{C}$, while the aqueous solution of ethylene glycol can be used at negative ambient temperatures. Thermophysical properties of these heat carriers are well known, which makes it possible to perform reliable thermal calculations.

One of the defining issues in conducting heat calculations was the choice of a criterial equation to calculate a heat transfer coefficient. As such channels have not been so far investigated, it became necessary to fabricate an experimental site and conduct experiments. A cooling jacket's scheme matched Fig. 1, $b$. We measured temperatures at the inlet and outlet from the channel using the chromel-alumel thermocouples, designed to control the temperatures of liquid media. We also measured the anode unit's surface temperature at three points, data on which were subsequently averaged. The channel's characteristics are as follows: a larger diameter $D_{z}=0.072 \mathrm{~m}$; smaller $d=0.052 \mathrm{~m}$; length $h_{z}=0.04 \mathrm{~m}$. The range of temperature change in a heat carrier $t=50 \ldots 100{ }^{\circ} \mathrm{C}$; a heat carrier volumetric flow rate $G=1.5 \cdot 10^{-4} \ldots 2.5 \cdot 10^{-4} \mathrm{~m}^{3} / \mathrm{s}$.

A SLC circuit to cool a single magnetron is shown in Fig. 2.

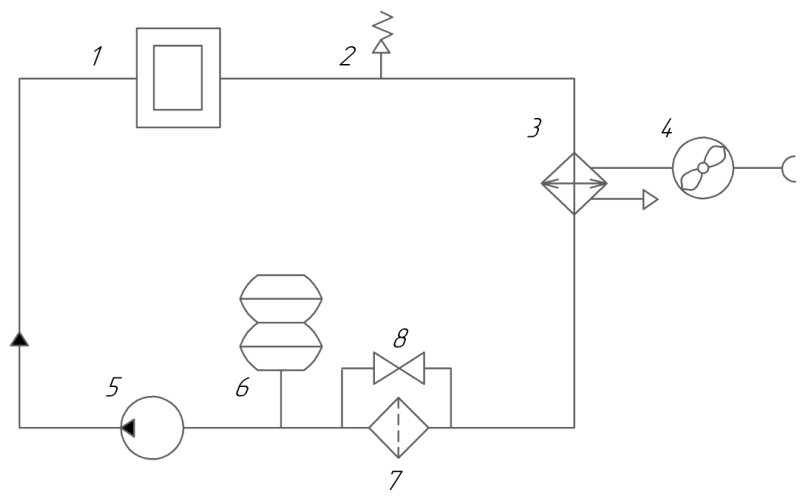

Fig. 2. A system of liquid cooling for a microwave device: 1 - magnetron, 2 - safety valve, 3 - air-liquid heat exchanger, $4-$ fan, 5 - pump, 6 - expansion tank, 7 - mechanical filter, 8 - bypass valve

SLC is filled with a heat carrier prior to launching a microwave installation. Upon filling, the automated system signals the readiness of magnetrons to operate. After the in- 
stallation enters a mode, indicated by signal lights at a control panel, the device may be set to an autonomous operation regime. After the end of the operation, SLC is automatically disabled.

\section{Analytical study of the operation of a system of liquid cooling for the magnetron's anode unit}

The purpose of a given calculation is to determine the temperatures of a heat-carrier at the inlet and outlet based on the condition for a maximally permissible surface temperature of the magnetron's anode unit.

We considered a magnetron with an output power of $1.0 \mathrm{~kW}$. In this case, power consumption is $N_{m}=1,200 \mathrm{~W}$. The power that must be removed from the anode unit is $Q=200 \mathrm{~W}$. The permissible surface temperature of an anode unit is $t_{a}=100{ }^{\circ} \mathrm{C}$. A cooling jacket is attached directly to the anode unit. The anode unit and cooling jacket are made of copper.

5. 1. Estimating the contribution of thermal resistances of heat conductivity of contact spots and an air gap

Any two surfaces in contact, regardless of the compression force between them, remain apart because of their rough surfaces. A gas, a liquid, various gaskets can fill the space between the surfaces, ensuring the presence of contact thermal resistance between them (CTR). Heat from one of the contacting surfaces in a general case can be passed by thermal conductivity through contact spots and by thermal conductivity through air medium. Air medium fills the space between ribs and irregularities at the contacting surfaces. Contact thermal resistance was determined in the following order.

The thermal resistance generated by air gaps:

$$
R_{v}=\frac{\delta}{\lambda_{v}}=0.016, \mathrm{~m}^{2} \cdot \mathrm{K} / \mathrm{W},
$$

where $\lambda_{v}=0.0313 \mathrm{~W} /(\mathrm{m} \cdot \mathrm{K})$ is the air heat conductivity at temperature $t=90{ }^{\circ} \mathrm{C} ; \delta=0.5 \cdot 10^{-3}$ is the gap thickness, $\mathrm{m}$.

The thermal resistance of contact spots:

$$
R_{m}=\frac{C \cdot \sigma_{v} \cdot S}{\lambda_{m} \cdot N}=8.94 \cdot 10^{-5}, \mathrm{~m}^{2} \cdot \mathrm{K} / \mathrm{W}
$$

where $C=1.43 \cdot 10^{-4}$ is a coefficient, $\mathrm{m} ; N=1.0 \cdot 10^{4}$ is the normal load, $\mathrm{N} ; \lambda_{m}=400$ is the coefficient of heat conductivity for copper, $\mathrm{W} /(\mathrm{m} \cdot \mathrm{K}) ; \sigma_{v}=350$ is the temporary resistance of a material, $\mathrm{MPa} ; S$ is the rated (geometric) contact area, $\mathrm{m}^{2}$.

Total contact thermal resistance:

$$
R_{\Sigma}=\frac{R_{v} \cdot R_{m}}{R_{v}+R_{m}}=8.9 \cdot 10^{-5}, \mathrm{~m}^{2} \cdot \mathrm{K} / \mathrm{W}
$$

Based on the derived thermal resistance, one can determine a temperature jump at a place of contact:

$$
\Delta t=q \cdot R_{\Sigma}=3.02 \cdot 10^{3} \cdot 8.9 \cdot 10^{-5}=0.27{ }^{\circ} \mathrm{C} .
$$

A temperature difference seems small, however, in order to refine the calculation of heat transfer the contact resistance should be taken into consideration.

\section{2. Calculating the liquid cooling mode of the mag-} netron's anode unit

The result of processing experimental data is the derived empirical dependence (5) for the mean heat transfer coefficient under conditions of forced fluid motion along an annular channel. When a model of the anode unit was cooled, we observed viscous and transient motion modes.

$$
N u=\frac{\alpha \cdot d_{z}}{\lambda}=0,22 \cdot P e^{0,38} \cdot R a^{0,1} \varepsilon_{t},
$$

where $R a$ is the Rayleigh number, calculated based on equivalent diameter of the channel; $\lambda$ is the coefficient of heat conductivity of a liquid; $P e$ is the Peclet number; $\varepsilon_{t}$ is the Mikheev temperature correction.

The proposed dependence takes into consideration patterns in the motion of a fluid in the cooling jacket, specifically, swirl in the flow leads to heat exchange intensification.

It was derived that the heat transfer coefficient is equal to $\alpha=2,718 \mathrm{~W} /\left(\mathrm{m}^{2} \cdot \mathrm{K}\right)$ when using water as a heat-carrier. In this case, the rate of a heat-carrier along the annular channel was $w=0.09 \mathrm{~m} / \mathrm{s}$. The heat transfer coefficient considering thermal resistance of the anode unit is equal to $k=2,189 \mathrm{~W} /\left(\mathrm{m}^{2} \cdot \mathrm{K}\right)$. Change in the temperature of water passing through a cooling jacket:

$$
\delta t=\frac{Q}{C p \cdot G}=1.04{ }^{\circ} \mathrm{C} .
$$

The mean temperature of a heat carrier:

$$
t_{g}=t_{a}-\frac{Q}{K \cdot F}=88.5^{\circ} \mathrm{C},
$$

where $t_{a}$ is the maximally permissible temperature of the anode unit's surface, ${ }^{\circ} \mathrm{C}$.

Then the temperature of water at the inlet to the cooling equals $t^{\prime}=88^{\circ} \mathrm{C}$, and at the outlet $-t^{\prime}=89^{\circ} \mathrm{C}$. Calculation suggests that the normal operation of a magnetron requires that the temperature of water at the inlet to the cooling jacket should not exceed $90{ }^{\circ} \mathrm{C}$.

When using a $54 \%$ aqueous solution of ethylene gly$\mathrm{col}$ as a heat-carrier, the heat transfer coefficient is equal to $\alpha=1,282 \mathrm{~W} /\left(\mathrm{m}^{2} \cdot \mathrm{K}\right)$. The temperature change in a heat carrier passing through the cooling jacket is $\delta t=1.2{ }^{\circ} \mathrm{C}$, the heat transfer coefficient $k=1,151 \mathrm{~W} /\left(\mathrm{m}^{2} \cdot \mathrm{K}\right)$, the mean temperature of a heat carrier is $t_{g}=76{ }^{\circ} \mathrm{C}$. The normal operation of a magnetron requires that the temperature of the aqueous solution of ethylene glycol at the inlet to the cooling jacket should not exceed $75^{\circ} \mathrm{C}$.

5. 3. Comparing heat carriers in terms of heat transfer efficiency. SLC circuitry for an industrial unit

Due to the better thermal-physical properties, the use of water as a heat-carrier is preferable. Our calculations have shown that when using water, a heat transfer coefficient $\alpha=2,718 \mathrm{~W} /\left(\mathrm{m}^{2} \cdot \mathrm{K}\right)$, when using a $54 \%$ aqueous solution of ethylene glycol as a heat-carrier, a heat transfer coefficient $\alpha=1,282 \mathrm{~W} /\left(\mathrm{m}^{2} \cdot \mathrm{K}\right)$. Thus, using water increases the intensity of heat transfer by 2.1 times. The heat transfer coefficient, taking into consideration thermal resistance of the anode unit, when using water, $k=2,189 \mathrm{~W} /\left(\mathrm{m}^{2} \cdot \mathrm{K}\right)$, when using ethylene glycol $-k=1,151 \mathrm{~W} /\left(\mathrm{m}^{2} \cdot \mathrm{K}\right)$. A heat transfer coefficient increases by 1.9 times. However, microwave installations may 
be operated at negative ambient temperatures, in this case there is a need to use aqueous solutions of ethylene glycol.

When designing microwave devices there is often the need to apply multiple magnetrons, depending on the estimated power consumption. In this case, a SLC's contour can include all cooling jackets in parallel. The hydraulic diagram of SLC, proposed to ensure thermal regimes for six magnetrons, is shown in Fig. 3.

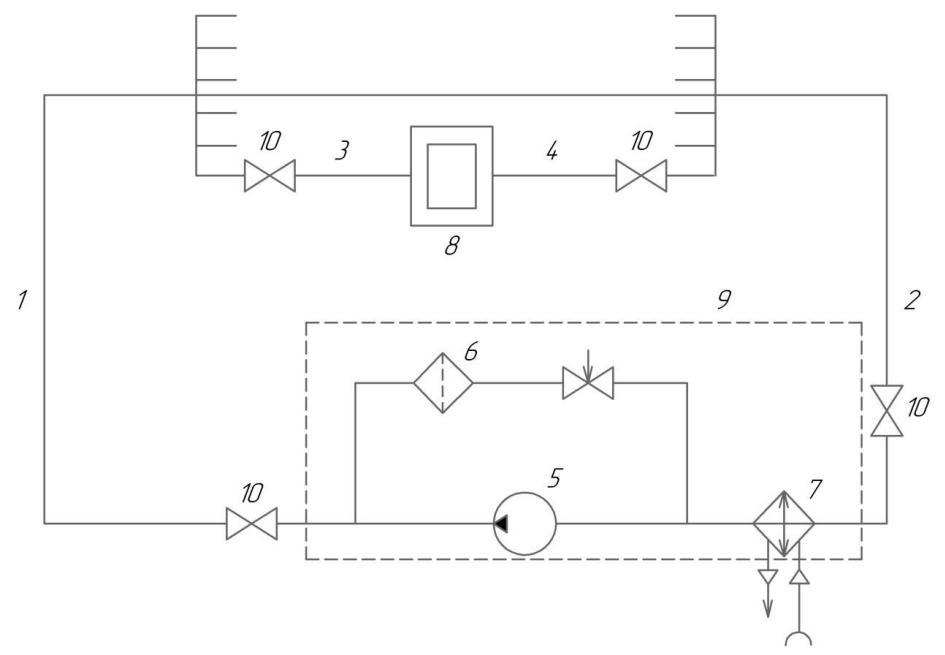

Fig. 3. SLC circuit for a microwave device: 1 - pressure line, 2 - suction line, 3 - inlet to the magnetron's cooling jacket,

4 - outlet from the cooling jacket, 5 - pump, 6 - filter, 7 - heat exchanger, 8 - magnetron, 9 - SLC contour, 10 - valve

Structurally, SLC can be executed taking into consideration a possibility to easily replace parts and to connect to a microwave device, as shown in the designed scheme.

\section{Discussion of results from studying heat exchange processes in a cooling jacket}

An optimal system to ensure thermal mode for magnetrons, which are part of the devices for heat treatment of materials during continuous and prolonged operation is the system of liquid cooling with a closed-loop circulation. The proposed replacement of the air-cooling system with the liquid system for low-power magnetrons would make it possible to stabilize temperature and improve reliability of the device. This implies installing a cooling jacket directly to the anode unit. The intensive heat exchange requires that the thermal resistance in a cooling jacket and the anode unit's surface should be maximally reduced. Our calculations show that the temperature difference in the place of contact between the anode unit's surfaces and the cooling jacket at a thickness of the gap of $0.5 \mathrm{~mm}$, considering contact resistance, does not exceed $0.3^{\circ} \mathrm{C}$. To calculate a heat transfer coefficient, we have proposed empirical dependence (5) derived from results of thermal experiments using a model. The use of water as a heat-carrier increases a heat transfer coefficient by 2.1 times compared with a $54 \%$ aqueous solution of ethylene glycol. This is due to the difference in the thermophysical properties. The heat transfer coefficient, taking into consideration the thermal resistance of the anode unit, is 1.9 times higher for water. Thus, using water appears to be preferable. However, at negative ambient temperatures it is recommended to fill the system of liquid cooling with aqueous solutions of ethylene glycol.

Merits of the current research are in that the conditions for establishing an estimated dependence were maximally close to actual thermal processes in the cooling jacket that makes it possible to obtain reliable estimates for such systems. It should also be noted that the proposed scheme for SLC implies application of multiple magnetrons, which is important in order to ensure the uniformity of heating a material in the device.

The limitation of the current study is that the calculations were carried out for the magnetron with a power output of $1 \mathrm{~kW}$, while it is possible to use low-power magnetrons with other characteristics.

In the future, it is advisable to consider the influence of geometric characteristics of a cooling channel on the intensity of heat transfer, as well as to undertake a research using a field sample in order to refine the estimates.

\section{Conclusions}

1. We have analyzed the influence of thermal resistances of the heat conductivity of contact spots and an air gap on heat transfer from the anode unit's surface to a heat carrier. At thickness of the air gap of $0.5 \mathrm{~mm}$ the total contact thermal resistance is $8.9 \cdot 10^{-5}\left(\mathrm{~m}^{2} \cdot \mathrm{K}\right) / \mathrm{W}$. At the heat flux density of $3.02 \cdot 10^{3} \mathrm{~W} / \mathrm{m}^{2}$ the temperature difference is $0.27^{\circ} \mathrm{C}$. It is advisable to take into consideration contact resistance to refine the calculation of a heat transfer process.

2. An empirical dependence has been established in order to calculate a heat transfer coefficient from the anode unit's surface to a heat carrier, circulating in the cooling jacket. To ensure the temperature mode for the anode unit's surface the temperature of water at the inlet to the cooling jacket should not exceed $88^{\circ} \mathrm{C}$, and that of the aqueous solution of ethylene glycol $-75^{\circ} \mathrm{C}$.

3. The heat transfer coefficient when using water as a heat-carrier at flow rate $w=0.09 \mathrm{~m} / \mathrm{s}$ along an annular channel, with an area of the heat exchange surface of $F=6.5 \cdot 10^{-3} \mathrm{~m}^{2}$, is $2,718 \mathrm{~W} /\left(\mathrm{m}^{2} \cdot \mathrm{K}\right)$, that is 2.1 times higher than while using a $54 \%$ aqueous solution of ethylene glycol. The heat transfer coefficient, taking into consideration thermal resistance of the anode unit, is 1.9 times higher than that for water. Application of ethylene glycol solutions is justified for the case when SLC operates at negative temperatures. The SLC circuit design makes it possible to include in the common contour the cooling jackets of all magnetrons, intended for the installation. Structurally, SLC can be executed taking into consideration a possibility to easily replace components.

\section{References}

1. Okeke, C., Abioye, A. E., Omosun, Y. (2014). Microwave heating application in food processing. IOSR Journal of Electrical and Electronics Engineering, 9 (4), 29-34. 
2. Bykov, Y. V., Egorov, S. V., Eremeev, A. G., Plotnikov, I. V., Rybakov, K. I., Semenov, V. E. et. al. (2012). Fabrication of metal-ceramic functionally graded materials by microwave sintering. Inorganic Materials: Applied Research, 3 (3), 261-269. doi: https://doi.org/ $10.1134 / \mathrm{s} 2075113312030057$

3. El-Naggar, S. M., Mikhaiel, A. A. (2011). Disinfestation of stored wheat grain and flour using gamma rays and microwave heating. Journal of Stored Products Research, 47 (3), 191-196. doi: https://doi.org/10.1016/j.jspr.2010.11.004

4. Puligundla, P. (2013). Potentials of Microwave Heating Technology for Select Food Processing Applications - a Brief Overview and Update. Journal of Food Processing \& Technology, 04 (11). doi: https://doi.org/10.4172/2157-7110.1000278

5. Burdo, O. G., Syrotyuk, I. V., Alhury, U., Levtrinska, J.O. (2016). Microwave Energy, as an Intensification Factor in the Heat-Mass Transfer and the Polydisperse Extract Formation. Problemele energeticii regionale, 1 (36), 59-71.

6. Mujumdar, A. S. (Ed.) (2014). Handbook of Industrial Drying. CRC Press, 1348. doi: https://doi.org/10.1201/b17208

7. Tikhonov, V. N., Ivanov, I. A., Kryukov, A. E., Tikhonov, A. V. (2015). Low cost microwave generators for plasma torches. Prikladnaya fizika, 5, 102-106.

8. Pozar, D. M. (2012). Microwave Engineering. Wiley, 756.

9. Bole, A., Wall, A., Norris, A. (2014). The Radar System - Technical Principles. Radar and ARPA Manual, 29-137. doi: https:// doi.org/10.1016/b978-0-08-097752-2.00002-7

10. Azarenkov, B. I., Kutsenko, A. S. (2013). Metodika i algoritm inzhenernogo rascheta temperaturnogo rezhima radioehlektronnoy apparatury. Visnyk natsionalnoho tekhnichnoho universytetu KhPI, 2 (976), 22-29.

11. Churyumov, G. I., Ehkezli, A. I. (2012). Modelirovanie chastotnyh harakteristik magnetrona s dvumya vyvodami ehnergii. Prikladnaya radioehlektronika, 11 (1), 63-71.

12. Lee, Y.-S., Lee, J.-S. (2003). A study on the cooling system of low power magnetron by using the natural convection heat transfer. 4th IEEE International Conference on Vacuum Electronics, 2003. doi: https://doi.org/10.1109/ivec.2003.1286123

13. Park, D. H., Seo, E. R., Kwon, M. K., Lee, C. S. (2019). A study on thermal fluid flow of magnetron cooling for microwave oven. Journal of Mechanical Science and Technology, 33 (4), 1915-1923. doi: https://doi.org/10.1007/s12206-019-0342-x

14. Aleksandrenkov, V. P. (2012). Issledovanie ehffektivnosti intensifikatsii teplootdachi v kol'tsevom kanale pri tsentral'nom teplopodvode. Vestnik MGTU im. N. Eh. Baumana. Ser.: Mashinostroenie, 4, 43-50.

15. Boltenko, E. A., Varava, A. N., Dedov, A. V., Zakharenkov, A. V., Komov, A. T., Malakhovskii, S. A. (2015). Investigation of heat transfer and pressure drop in an annular channel with heat transfer intensifiers. Thermal Engineering, 62 (3), 177-182. doi: https:// doi.org/10.1134/s0040363615030017

16. Dirker, J., Meyer, J. P. (2005). Convective Heat Transfer Coefficients in Concentric Annuli. Heat Transfer Engineering, 26 (2), 38-44. doi: https://doi.org/10.1080/01457630590897097 